\title{
Hatékony helyi gazdaságfejlesztés a Biblia alapján és napjainkban ${ }^{1}$
}

\section{Efficient Local Economic Development Based on the Bible and Today}

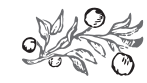

\section{Összefoglalás}

A gazdaságfejlesztésnek alapvetôen két útja ismeretes. Az elsố esetben úgy próbáljuk fokozni egy térség versenyképességét, hatékonyságát, hogy külsô támogatókat, befektetôket vonunk be, akiknek a játékszabályaihoz alkalmazkodnunk is kell. A második megoldás szerint a helyi erôforrásokra támaszkodunk, a közösség társadalmi és gazdasági tôkéjére építjük a gazdaságot. Ez utóbbi szükségessé teszi a helyi szereplôk erôteljes bevonását, amit természetesen ók elkötelezôdésükkel, lokális beágyazottsággal hálálnak meg. A gazdaságfejlesztés második, helyi tôkére építô megoldása azonban elérhetetlen marad a közös etikai normák megléte, folytonossága és alkalmazása nélkül. A gazdaságfejlesztés etikai irányelveit jelen publikáció az európai erkölcsiséget meghatározó zsidó-keresztény örökség alapján bontakoztatja ki, majd a hasonló elvek mentén gondolkodó, napjaink közös értékteremtése felé fordul. Mindezt a szakirodalmak összehasonlításával és esettanulmányok elemzésével szemlélteti.

Journal of Economic Literature (JEL) kódok: B11, D63, M14, Z12

Kulcsszavak: helyi gazdaságfejlesztés, tisztességes verseny, társadalmi igazságosság, közös értékteremtés

Balassa Bernadett PhD-hallgató, Széchenyi István Egyetem, Regionálisés Gazdaságtudományi Doktori Iskola (balassa.bernadett@sze.hu). 


\section{Summary}

Economic development shows two determined ways. The first approach tries to improve local competitiveness and effectiveness through external support, but it must adapt to hierarchical regulations. From another view economic development relies on local resources, the social and business capital of the examined community. The latter solution needs to involve local stakeholders actively, who will implanted to the society in a long run. Achieving the mentioned bottom-up development is impossible when there is no mutual ethical norms to apply. This publication highlights the ethical intstructions of the Jewish-Christian heritage as a determining factor for European morality, and thereafter points to the modern application of Creating Shared Value methodology. The study represents this by comparing given theoretical bases and analyzing case studies.

Journal of Economic Literature (JEL) codes: B11, D63, M14, Z12

Keywords: local economic development, fair competition, social justice, Creating Shared Value

\section{BEVEZETÉS}

Napjaink modern, jól szervezett társadalmában sokszor magától értetődônek tartjuk azokat az intézményesült formákat, kereteket, amelyekben hétköznapjainkat bonyolítjuk. Megszoktuk, hogy rendje és módja van a vállalkozásalapításnak, különféle adókat fizetünk az államnak, amely a jövedelemelosztás révén gondoskodik azokról a honfitársainkról is, akik pillanatnyilag rászorulnak. Az idônként túlzásba hajló bürokratizmusról, az állam jó szándékú, de esetenként megkérdőjelezhetô hatékonyságú gazdasági szerepvállalásáról számos kritikai észrevételt találunk, kormányzati kudarcok vagy government failures néven (Bod, 2006). Ugyanakkor vitathatatlan, hogy az egyes pénzügyi krízisek sikeres menedzselésére (Lentner, 2014) és annak helyi szinten gyakorolt kedvezố hatásaira is találunk példákat (Lentner, 2015).

A kormányzati kudarcok mégis indokolttá teszik, hogy a közösségi, alulról jövô, nem hierarchikusan irányított gazdaságfejlesztés felé forduljunk, ettôl várjuk a kreativitás és újító szándék átütő erejét. Amikor az állam szerepvállalásáról beszélünk, gyakran elkövetjük azt a hibát, hogy a bennünket illető terhek, szabályok csökkentését áhítjuk - ilyenkor egy minimalista államban gondolkodunk -, a jóléti intézkedések tekintetében viszont továbbra is a kormányzattól várjuk a megoldásokat. A kettő együtt azonban nem megy. Az írás elôször a tradicionális gazdálkodás kereteit vizsgálja, lebontva a modern társadalomszervezés jól megszokott rétegeit, egy már-már idealisztikus, de véleményem szerint a helyi gazdaságfejlesztés iskolapéldájaként szolgáló modell felé fordulva. A Biblia gazdasági tanításának summázását követôen olyan modern üzleti megoldásokat keres, amelyek a vállalatok kizárólagos hasznán túl az azt körülvevô közösség, helyi gazdaság és társadalom számára is áldást jelentenek. 


\section{A TRADICIONÁLIS GAZDÁLKODÁS BIBLIAI KERETEI}

A Biblia ugyan két nagy szöveggyújteményből, az Ó- és Újszövetségbôl áll, alapvetô üzenete mégis egységes: „Szeresd az Urat, a te Istenedet... és felebarátodat, mint önmagadat" (Lk 10,27). A társadalmi együttélés szabályait a mózesi törvény fektette le, amely elsố ránézésre rigorózus parancsgyújteménynek hat, azonban egymás és a természet kizsákmányolását gátolja. A két testamentum üzenetének eltérô súlypontja a könyvek keletkezésének idejére is visszavezethetô. Ameddig az elóbbi egy többnyire szabad, törzsi, késóbb királyi uralom alatt álló zsidó nép történetét és a nekik szóló útmutatásokat rögzíti, addig a názáreti csodarabbi, Jézus szavai egy elnyomásban, római provinciaként múködô, hierarchizált társadalom tagjaihoz szólnak. Az elkülönítés tekintetében elsôsorban az ószövetségi szövegrészek alkalmasak a helyi, alulról jövố gazdaságfejlesztés modellezésére, etikai kereteinek meghatározására. Ezért a publikáció az Ótestamentum gazdasági tanítását veszi alapul, figyelembe véve a helyi közösségfejlesztéshez kapcsolódó etikai normákat.

Az ókori zsidóság életében központi szerepet játszott a Tóra és a Tanakh ${ }^{3}$ tanítása, melyek szövege történelmük megismerésének is - sok esetben régészetileg igazolt - elsôdleges forrása. A gyújteményes múvekboól megtudhatjuk a zsidó nép keletkezésének és kiválasztásának történetét, népvándorlásait, letelepedését és közigazgatási jellegét. A Szentföldrôl történố szétszóródás elôtti idôszakot (i. e. kb. 2400 - i. sz. 135) kronológiailag 7 szakaszra bonthatjuk:

1. A Termékeny félhold felosztása, az elsố városok kialakulása

2. Ábrahám kiválasztása és letelepedése (i. e. 2200-1900)

3. Egyiptomi évek és exodus (i. e. 1876-1406) - párianép

4. Honfoglalás, bírák kora (i. e. 1400-1050)

5. Királyság kora (i. e. 1050-586)

6. Fogság és helyreállítás (i. e. 722-538)

7. Idegen fennhatóság (i. e. 538 - i. sz. 135) - benne a názáreti Jézus színrelépése

A felsorolt szakaszok közül jelen publikációban a 4-6. szakaszokra koncentrálunk, ezek közül is fóként a Mózessel kötött szövetségtốl a királyok koráig érdemes vizsgálódnunk. A Teremtés könyvének beszámolója szerint Ur városából hívta ki Isten a zsidóság ôsatyját, az elsố pátriárkát. Ezáltal Ábrám és családja a többi népcsoporttól és törzstôl elkülönülten élố ún. párianéppé vált, „a környezố társadalmi világtól rituálisan, formálisan vagy ténylegesen elkülönült vendégnép” lett belőle (Weber, 2007:448), egészen a saját földjén való letelepedésig.

\section{Kormányzati modellek az Ószövetség idején}

I. e. 1400 tájékán az izraeliták bevonultak Kánaán és Palesztina területére. A népcsoport ôsatyjának tartott Ábrahámot héberként jelölik az írások, ezzel az elnevezéssel illetik a sémita (Noé fiától, Sémtôl származtatott) etnikumot. A pontos megfogalmazást az ókortörténész Grüll Tibortól kölcsönzöm: „ma a népet zsidónak, vallását judaizmusnak, nyelvét hébernek, országát pedig Izraelnek" nevezzük 
(Grüll, 2013:98-99). Jákob tizenkét fia megalapította Izrael tizenkét törzsét, ók érkeztek meg Kánaán földjére.

A Sínai-hegyi szövetségkötést követôen Izrael államformája teokrácia, vagyis istenuralom lett, melyben a legfóbb uralkodó transzcendens lény, az adott kultúra Istene, kinek földi képviselôi elôször a bírák, majd a királyok voltak. Az állami berendezkedés alapját a mózesi törvények alkották, mindösszesen 613 parancsolat, amely a mindennapi együttélést és az istentisztelet rendjét szabályozta.

A törzsek szuverenitása megmaradt, az igazgatási feladatokat törzsenként látták el, csupán az Istennel kötött szövetség és annak parancsolatai hozták közös nevezôre a területi entitásokat. „Izraelben a királyságot megelőzôen bármilyen szokásjog és vallási jellegú jogi intézmény csupán a tizenkét törzs közös szövetségén belül alakulhatott ki, amely jogalkalmazás tekintetében egységes jelleget öltött” (Tokics, 2011:90). Ugyanazért a helytelen cselekedetért tehát azonos joghátrány érte az elkövetôt, bármelyik törzs területén is mozgott. A törzsek ilyen jellegú szövetségének élén annak felügyelői, a bírák álltak, akik „az igazságszolgáltatás, a polgári élet irányítása és a katonai vezetés feladatain túl, egyfajta népvezérek, vallási reformerek, Isten követei és közvetítői is voltak. Alapvetően Isten törvényét, a mózesi törvényeket kívánták betartatni Izrael fiaival" (Sola Scriptura, 2012).

Az izraeliták tehát i. e. 1050-ig a már ismertetett decentralizált társadalomban éltek - a bírák közigazgatási és a papok, valamint próféták szellemi vezetése mellett -, de a környezô népek államformája jellemzôen királyság volt. Sámuel próféta korrupt fiait látva, a nép magának is abszolút vezetôt, királyt követelt, a vonatkozó bibliai szakaszokból azonban kiderül a könyv szerzőjének véleménye a hierarchikus irányításról (1Sám 8,11-18). A próféta olyan gazdasági eseményeket említ a hierarchikus államszervezódés hátrányaként, mint a magánvagyon államosítása, a kötelezô munkaszolgálat, a magas adóterhek, a hadkötelezettség; sốt a korrupció különbözô válfajait (jogosulatlan gazdasági elóny szerzése, nepotizmus, befolyással való üzérkedés) is idesorolja.

A nép kérésére végül Sámuel próféta felkente Sault, Izrael elsô királyát, de a törzsek valódi egységét csak az ôt követô Dávid teremtette meg. Dávid király uralkodása alatt Izrael elérte legnagyobb kiterjedését, a Nílustól az Eufráteszig terült el, de kereskedelmi kapcsolatai még tovább nyúltak. Dávid legnagyobb érdeme az egységes, katonailag is számottevô erôvel bíró nagyhatalom létrehozása volt, amit aztán fia, Salamon tett a térség nemzetközi rangú központjává. Salamon korában a bürokratikus intézményrendszer is megerôsödött.

A kormányzati modellek áttekintése során láthattuk, hogy Izrael jogrendszerének alapját a mózesi törvények alkották, amely az állam alkotmányos berendezkedését is meghatározta. A törzsszövetségi rendszer idején kizárólag a jogi háttér volt egységes és bírák által felügyelt, a hétköznapi élet apró-cseprô ügyeibe nem szólt bele felettes hatalom. A királyság idején a korábbi függetlenséget felszámolták, és habár a területi egység jogi és etikai rendelkezései ugyanúgy a Tórán nyugodtak, a mindennapi élet bürokratikusabbá, felülrôl szervezetté vált. A két modell ismeretében fordulunk most azon ószövetségi parancsolatok felé, amelyek szabályozták az együttélés gazdasági feltételeit. 


\section{A helyi gazdaságfejlesztés ószövetségi útmutatásai}

Az ószövetségi gazdálkodás alapegysége a család, a magántulajdonhoz való jog is ehhez az intézményhez kapcsolódik. Fontos belátni, hogy a család egységének és tulajdonának folytonosságához a Biblia képes korlátozni mind az egyének, mind az állam hatalmát (North, 1973). Az ószövetségi törvények 19. századi teológiaprofesszora, Oehler így értelmezi a teokrácia és a magánjog érvényesülését: „Mivelhogy minden család a teokrácia egységes részét képezte, Isten örökségi formában biztosította megélhetésüket.” Örökletes húbéri birtokot képzeljünk el, amelyhez a családokat elidegeníthetetlen jog fúzi (Oehler, 1883:235). A törzsek területének meghatározásával az ahhoz tartozó családok helyét is kijelölték (Józs 13,1-33). Egyedül a papságot biztosító Lévi törzse nem kapott földterületet, ők a többi törzs adományaiból (tized) részesültek, és a számukra kijelölt levita városokban éltek.

A teljes törvény üzenete összefoglalható a két nagy parancsolatban: „Jézus pedig monda neki: Szeresd az Urat, a te Istenedet teljes szívedból, teljes lelkedból és teljes elmédből. Ez az elsố és nagy parancsolat. A második pedig hasonlatos ehhez: Szeresd felebarátodat, mint magadat. E két parancsolattól függ az egész törvény és a próféták” (Mt 22,37-40). A két nagy parancsolat részletezése a tízparancsolat is, amelynek elsố négy parancsolata Istenhez, a második kôtáblán található rendelkezések pedig az embertársakhoz fưződő viszonyt harmonizálják. Mind a tíz parancsolatból kibontható gazdasági útmutatás, amelynek egyszerú átlátását szolgálja az 1. ábra.

\section{1. ábra: A Biblia gazdasági üzenetének rendszerezése}

Szeresd az Urat, a te Istenedet teljes szívedbôl, teljes lelkedbôl és teljes elmédbổ.
Szeresd felebarátodat, mint magadat.

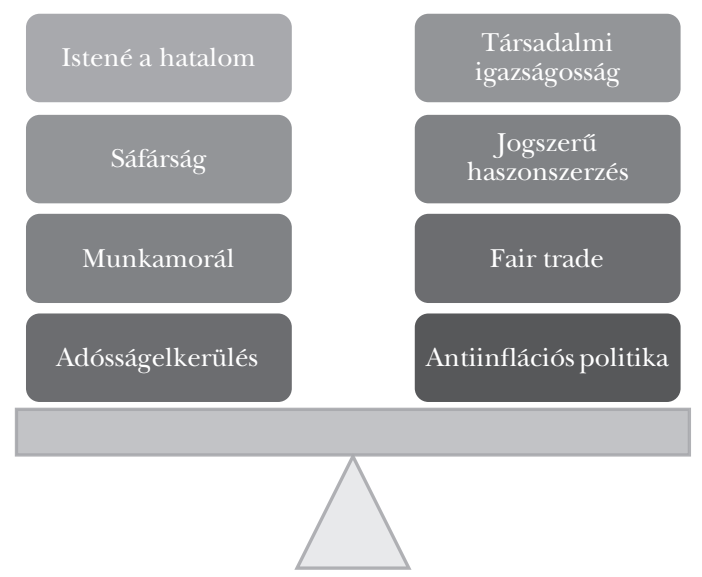

Forrás: Saját szerkesztés 
Az Ószövetség gazdasági tanítása alapvetôen két nagy pilléren áll: az adósságok elkerülésén (szabadság megórzése), valamint a társadalmi igazságosság biztosításán. Ezeken túlmenôen viszonylag nagy gyakorisággal találunk a tisztességes versenykörnyezet kialakítására vonatkozó szabályokat, illetve fair trade-del, helyes fogyasztói magatartással is foglalkoznak az írások. A következô alfejezetek az adósságok elkerülésével, a társadalmi igazságosság és a tisztességes verseny feltételeinek megteremtésével, mint a helyi gazdaságfejlesztés alapkritériumaival foglalkoznak.

Az adósságok elkerülése és elengedése

Az Ószövetség gazdasági tanításának jelentôs hányada a kölcsönnel, záloggal és adósságokkal kapcsolatos. Az Újszövetséghez képest itt jóval markánsabban jelenik meg ez a típusú üzenet, és mondhatjuk, hogy a Tóra gazdasági parancsai leginkább a szabadság és függetlenség megórzésére vonatkoznak. Egyrészt óvta a népet attól, hogy bárki is hét évnél hosszabb futamidôre vegyen fel személyi kölcsönt - a Tóra szerint ennél hosszabb idôre nem vállalhatunk garanciát -, másrészt felhívja a figyelmet arra, hogy a kölcsönvevő függóségi viszonyba kerül a hitelezőtől (Péld 22,7). Hasonló elv vonatkozott a rabszolgákra is, ugyanis azokat, akik nem voltak képesek visszafizetni az adósságot, kényszermunkára bírhatták, legfeljebb hét évre.

A hetedik évben azonban fel kellett szabadítani a rabszolgákat, eltörölni az adósságot, függetlenül attól, hogy leszolgálta-e az illetô a tartozását, vagy sem. „A hetedik esztendố végén elengedést múvelj. Ez pedig az elengedésnek módja: Minden kölcsönadó ember engedje el, amit kölcsönadott az ô felebarátjának; ne hajtsa be az ô felebarátján és atyjafián; mert elengedés hirdettetett az Úrért" - mondja ki a szombatév (smítá) törvénye (5Móz 15,1-2). A késôbbi indoklásból kiolvasható, hogy mindennek célja az, hogy megtörje az adósságok felhalmozódását, eltörölje a szociális nélkülözést. A szombatévre egy másik elóírás is vonatkozott, amit a hatnapos teremtéssel és az azt követô pihenónappal hoz összefüggésbe az írás. Hat éven át lehetett vetni egy adott szántóterületen, a hetedik évben azonban ugaroltatni kellett. Ami a hetedik évben magától megtermett a földön, azt nem volt szabad learatni, sem kereskedni vele, csupán a háztartás szükségleteit elégíthette ki (3Móz 25,1-7). A monoteista vallásban ez a megnyugvás az isteni gondviselésbe vetett bizalmat hivatott erôsíteni.

Ennél is érdekesebb az adósságok elengedésének másik módja, amit a hét szombatévet követô ötvenedik év törvénye tartalmaz. A jubileum (vagy kürtölés) évének megtartását ötvenévenként írta elô a törvény, amikor nemcsak a pénzbeli adósságokat és a rabszolgákat kellett elengedni, valamint a szántóföldet ugaroltatni, hanem az elzálogosított ingatlanokat, birtokot is vissza kellett szolgáltatni az eredeti tulajdonosnak (3Móz 25,8-23). Az adósságok eltörlésével minden ingatlan a korábbi birtokosok kezéhez jutott, ami megvalósítható volt, hisz a honfoglaláskor a törzsek és családok meghatározott földterületet kaptak. Mindez meggátolta, hogy az adósságok generációról generációra felhalmozódjanak, így a szülôk téves döntései után a leszármazottak tiszta lappal, új lehetóségekkel indulhattak (Cahn, 2014). 
A jubileumi évhez kapcsolódóan sok kutató azt fejtegeti (North, 1973; Hack 2014; Bohács, 2015), hogy a Biblia által preferált gazdasági rendszer se nem kommunista (hiszen a közösségi tulajdonlást nem pártolja), se nem kapitalista, ugyanis nagyjából Kondratyev-ciklusnyi időtávonként (kb. 50 év) kiigazítja a jövedelemkülönbségeket. Egy ilyen rendszer ténylegesen gátolja a végletesen nagy vagyoni egyenlôtlenség létrejöttét, ellentétben korunkkal, amikor a történelem talán legnagyobb aránytalanságait éljük meg. A társadalmi igazságosság jegyében Tomas Sedlacek is kifejti, hogy a gazdaságpolitikusok feladata nem feltétlenül a gazdaság teljesítményének növelése, hanem a kilengések (expanzió és recesszió) mérséklése, a gazdasági stabilitás biztosítása (Sedlacek, 2012).

Cedaka, vagyis társadalmi igazságosság

Az egyenlőségre és igazságosságra való törekvés a zsidó társadalometika alapja - fogalmazza meg Háberman (2013). A 613 tórai parancsolatot a rabbik és próféták egyetlen parancsolatban, a cedaka parancsában foglalták össze. Háberman kiemeli, hogy az általános vélekedéssel ellentétben a cedaka nem csupán perselyezést, adakozást, jótékonykodást jelent, hanem a közjó előmozdításáért hozott erôfeszítéseket. Habár a modern társadalmakban szinte kizárólag állami feladatnak tekintjük a társadalmi igazságosság megteremtését és a szociális háló fenntartását, az ókori és feudális - összefoglalóan premodern - társadalmakban ezt a funkciót a családok és az egyház látta el.

A társadalmi igazságosság elérése nyilvánvalóan az eróforrások szúkösségébool indul ki, az azok iránti szükségleteket szeretné mindenki számára kielégíthetôvé tenni (5Móz 8,9). Vannak olyan társadalmi csoportok, amelyek potenciálisan az elszegényedés, szúkölködés útjára léphetnek, éppen ezért különleges figyelmet szentelnek az írások e csoportoknak. Így például számtalan felszólítást találunk az árvák és özvegyek támogatására (összesen 42 utalás, többek között: 2Móz 22,22). Az írás felszólítja a munkaképes népességet, hogy gondoskodjon a rászorulók táplálásáról és ruházkodásáról (hasonlóan a modern szeretetszolgálatokhoz), ingatlanhoz és jövedelemhez való hozzáférésérôl, adómentességérôl. Ezek a csoportok adományból - a tizedként befizetett részból - részesültek a papok mellett. Néhol ugyanebbe a csoportba sorolja a Tóra a jövevényeket is, azokat a bevándorlókat, akik a közösség tagjaivá szeretnének válni, integrálódni (nem rendelkeznek földtulajdonnal és biztos egzisztenciával). Összefoglalóan, a társadalom mindezen tagjai önhibájukon kívül, helyzetüknél fogva anyagi kilátástalanságban élnek, ezért a Tóra a magánszemélyek számára szinte kötelezó érvényúvé teszi a támogatásukat.

Vannak olyan családok, személyek is, akik döntéseikból, körülményeikból fakadóan szegényedtek el, számukra azonban nem ígér anyagi juttatást a Tóra, hanem a munkavégzéshez és az alapvetô élelmiszerekhez való hozzáférést teszi lehetôvé. A gabonamezôn leejtett kévéket az aratók nem szedhették fel, ez a szegények és a korábban említett árvák, özvegyek és jövevények joga volt (5Móz 24,19-21). A szegények számára tehát nem egyoldalú transzferjövedelmet biztosított a közösség, hanem a gyújtö- 
getésre való lehetôséget adta meg, csakis munka árán elégíthették ki szükségleteiket. Ezenkívül kamatmentes hitelt is kínáltak a szegény rétegek számára (2Móz 22,25), melyen keresztül megérthetjük a kamattilalom törvényét. A kamatmentes kölcsön szintén a munkavégzésre való ösztönzés, hiszen jövedelméból késóbb visszafizethető a kapott hitel.

\section{Tisztességes verseny}

A vállalatok egymás közötti tranzakcióira is találunk bibliai szankciókat. „Ha pedig eladsz valami eladni valót a te felebarátodnak, vagy vásárolsz valamit a te felebarátodtól: egymást meg ne csaljátok" - figyelmeztet a Tóra (3Móz 25,14). Érdekes módon a Talmud még a lehetséges profitmarzs mértékét is meghatározza: az áru értékének legfeljebb egyhatoda lehet; ha ennél magasabb árat szabnak, az adásvétel érvénytelen (Baba Mezi’a 50b). Nemcsak a vevôket, hanem az előadókat is védi ez a törvény, ugyanis a vásárló sem használhatja ki az eladó tudatlanságát, amennyiben az túl alacsony árat szab, az etikus magatartás ez esetben is a tisztességes ár megfizetése. Az említett etikai korlátozásokkal az információs aszimmetriából fakadó kontraszelekciót gátolja a törvény, így a termékek forgalma egyensúlyban marad azok valódi értékével.

A monopolisztikus helyzetben lévô vállalat sem használhatja ki versenyelônyét a fogyasztók lefölözésére vagy az alkalmazottak alulbérezésére. A vásárlók megtévesztése, a termék jobb színben való feltüntetése szintén a törvény áthágását jelenti. Különös módon az infláció generálását legalább akkora vétségnek tartották a talmudi bölcsek, mint az uzsoraszedést, vagy a súlyokkal és mértékegységekkel való csalást (Friedman, 2000). „Aki búzáját visszatartja, átkozza azt a nép; annak fején pedig, aki eladja, áldás [van]" - mondja Bölcs Salamon (Péld 11,26). A termékek készleten tartása nyilvánvalóan csökkenti a pillanatnyi piaci kínálatot, ami alapvetô élelmiszerek esetén nagyjából állandó, ezzel túlkeresletet generál. Az eladó rövid távú döntése felhajtja a termény egységárát, az árut pedig késôbb a már megnövekedett áron kínálja. Az ókori gazdák ezzel az egyszerú húzással nagyobb egyéni haszonra tehettek szert, az árszínvonalat viszont tartósan megemelték. Az idézett példabeszéd ugyanakkor rámutat az efféle viszonyulás káros hatásaira is: hosszú távon nem lesz eredményes az így trükközô vállalkozó, cselekedete rendkívül negatívan hat a hírnevére. A társadalmi megítélés, megbecsülés fontosságát egyébként is nagyra tartják a Biblia bölcseleti könyvei. Rámutatnak, hogy az etikus gazdálkodó jó hírnévre tesz szert, ami hosszú távon sokkal többet ér - anyagilag is kifizetôdőbb -, mint mindenáron a profitnövelésre koncentrálni (Péld 22,1; Préd 7,1).

\section{A Szentírás véleménye a közösségi és hierarchikus gazdaságfejlesztésrôl}

Az ókori Izrael területén a gazdasági élet számára is adekvát erkölcsi keretrendszert biztosított a Tóra. A törvénygyújtemény etikai alapon szabályozta a mindennapi adásvételek, üzleti tranzakciók kereteit, ezek többsége ajánlásokat, útmutatásokat fogalmaz meg. Vannak természetesen szigorú szankciók is, amelyek a másik ember (üz- 
lettárs, beosztott, munkatárs, fônök, hitelezô, beszállító stb.) életének, vagyonának a megrövidítését gátolják. A bibliai törvények közül nagyon sok alapjaiban fogalmazta újra a nyugati civilizáció munkavégzéshez, meggazdagodáshoz, hitelezéshez való hozzáállását, ahogy ezt Schmidt (2004) is kiemeli.

Vajon mivé lett, hová vezetett a királyi fennhatóság Izrael földjén? Vajon az újonnan bevezetett hierarchikus vagy az azt megelőzô törzsi, közösségi gazdaságfejlesztés bizonyult sikeresebbnek? A választ is az írásokban találjuk. Már a bürokratikus kereteket kialakító Salamon, az egységes Izrael harmadik királya idején elindult az új államigazgatási rendszer hanyatlása. Fia, Roboám regnálásakor - közvetlen okát tekintve adóemelés miatt - kettészakadt a királysága (Izraelre és Júdára). Néhány nemzedék elteltével pedig, különbözó pártütéseket és gyilkosságokat követően, már szinte hetente váltották egymást az uralkodók.

Izrael és Júda lakosai ezekben a zivataros évszázadokban a mózesi törvényeket sem tartották meg maradéktalanul, a prófétai könyvek ezzel magyarázzák az asszír, illetve babiloni fogságra vitelt. Többek között Ámos próféta is megjelöli a számúzetés okát, amikor így fogalmaz: „Mikor telik már le az újhold - mondjátok -, hogy gabonával kereskedjünk, meg a szombat, hogy terménnyel piacozzunk: kisebb mérôedénnyel, nagyobb súlyokkal meg hamis mérleggel csaljunk, hogy pénzen felvásároljuk a gyengéket, a szegényeket meg egy pár saruért, és eladjuk a hulladék gabonát!" (Ámos 8,5-6 SZPA fordítás).

Összefoglalva, azt láthatjuk, hogy önmagában a központosítás, a gazdaság bürokratizálása nem vezetett sikertörténethez az ókori Izrael területén, ehelyett a Sámuel által megjövendölt baljós eseményeket igazolta. A túlzott hierarchia ugyanis negligálta a közösség erkölcsi erejét, megszakította a korábban múködô szociális hálót, és nem tudott erôsebb gazdasági alapzatot csomózni belóle. Mindezek fényében kimondható, hogy a Szentírás alapvetôen az alulról jövô, központilag nem túlzottan szabályozott gazdaságot preferálja, amit Sámuel próféta a királyság intézményének megalapítása elôtt deklarált. A jól múködô közösségi gazdaságfejlesztéshez azonban erkölcsi normák, megfelelố szabályrendszer szükséges, amit a Törvény biztosított számukra.

\section{A HELYI GAZDASÁGFEJLESZTÉS}

HATÉKONY GYAKORLATA NAPJAINKBAN

Az alulról jövô, közösségi gazdaságfejlesztés elônyeire nem csupán a Biblia, hanem a modern regionális tudomány is rámutat (Rechnitzer et al., 2016). A helyi aktorok bevonását azért is tartja szerencsésnek a teória, mert erôsíti a térségben tartózkodó cégek beágyazottságát (Józsa, 2017), támogatja a hosszú távú együttmúködésekben rejlő fejlôdési lehetôségeket (Filep, 2014; Fekete, 2015b).

Az alulról jövô, ún. bottom up gazdaságfejlesztés sikerét tehát a helyi szereplôk öszszefogása adja, melyet a Triple Helix (Eztkowitz-Leydesdorff, 1996), újabban a Quadruple Helix (Arnkil et al., 2010) modell propagál. A modellek rámutatnak a gazdasági (fôként ipari), kormányzati, akadémiai és civil szereplók együttmúködési lehetôségei- 
re. A közös gazdaságfejlesztés céljait és hatását erôteljesen befolyásolja, hogy melyik szereplố dominál az adott modellben. E szerint beszélhetünk üzleti célokat elôtérbe helyezô vállalatok által vezérelt, hierarchiába hajló kormányzatvezérelt vagy civil központú gazdaságfejlesztésrôl (Arnkil et al., 2010). Megítélésem szerint a Biblia említett elveivel leginkább összhangban lévố modell az utóbbi, civil szektort középpontba helyezô megoldás, hiszen ez ismeri fel és szolgálja leginkább a társadalom érdekeit.

A civileket középpontba állító helyi gazdaságfejlesztés célja a lakosság/térség igényeinek felismerése, azok kielégítése. Ez egy alapvetốn pull típusú fejlesztés, amely nem a már meglévô innovációt, terméket tolja a fogyasztókra, hanem a szükségletekhez próbál alkalmazkodni. Az említett relációban megjelenhetnek olyan szükségletek is, amelyeket klasszikusan közszolgáltatásként, nem kifejezetten forprofit módon szokás kielégíteni, de az ismertetett modell képes ezt is a vállalatok számára jövedelmezó módon végezni. A 2. ábrán leírt gazdaságfejlesztés elônye, hogy csökkenti a lakosság innovációtól, technológiától való félelmét, hiszen a saját igényeik generálták az üzleti tevékenységet.

2. ábra: A helyi gazdaságfejlesztés civil központú Quadruple Helix-modellje

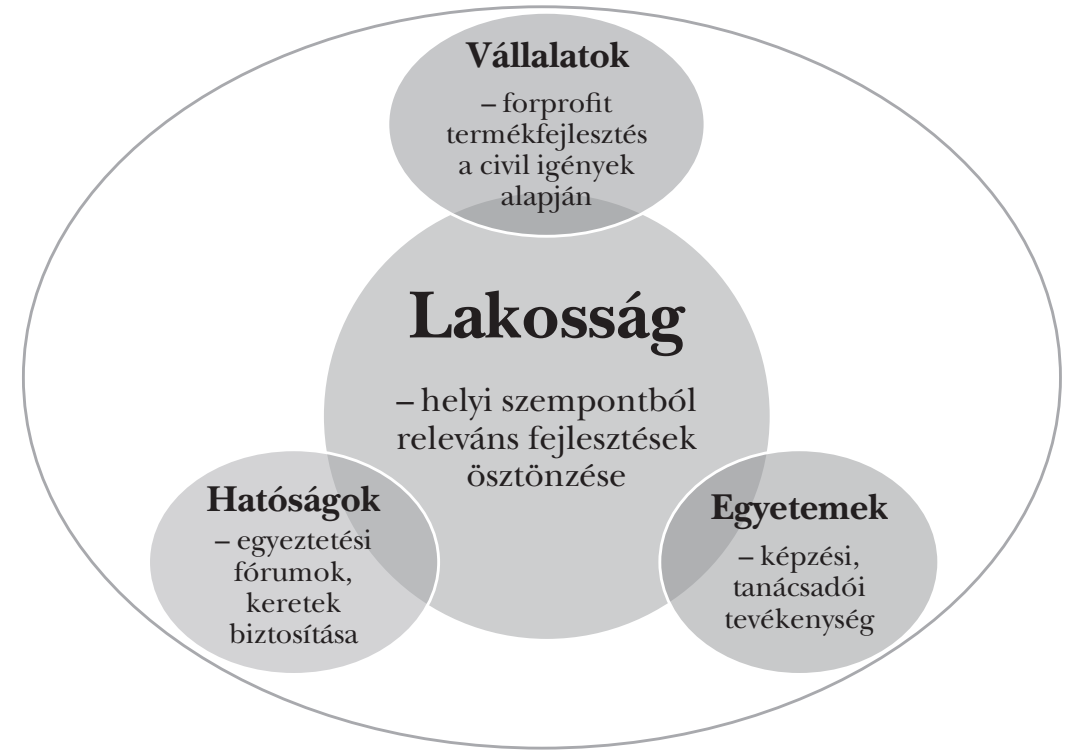

Forrás: Saját szerkesztés Arnkil et al., 2010:56 alapján

\section{Közös értékteremtés}

Az 1970-es évek óta a cégek üzleti etikai botrányai egyre erôteljesebb médiavisszhangot nyernek, így a civilek igénye megnôtt a vállalatok társadalmi felelôsségvállalása (Corporate Social Responsibility, CSR) iránt (Csiszárik-Kocsir, 2016). A CSR klasszikus célrendszerét (Carroll, 1979) azonban számos kritika érte a felelôsségvállalás és a 
vállalati stratégiában való integráltság alacsony foka miatt (pl. Geva, 2008). Gyakran szembesülünk ugyanis azzal, hogy bizonyos vállalatok társadalmi vagy környezeti szempontból vitatható tevékenységüket palástolva, ezt leplezve jótékonykodnak, amely zömében a közönségkapcsolatok javítását célozza (Győri, 2012).

A felelôsségvállalás autentikusabb megoldását szorgalmazza Porter és Kramer közös értékteremtés (Creating Shared Value, CSV) módszertana (Porter-Kramer, 2011). A szerzók szerint az új stratégia célja a kapitalizmus újraformálása, a profitérdekelt vállalkozások és a társadalmi szükségek összekapcsolása. Az új mechanizmust azóta számos vállalat alkalmazza, a kis méretúektôl a multinacionális nagyvállalatokig. Az egyik érintett vállalat tulajdonosa, Jeff Brown frappánsan fogalmazta meg a módszer lényegét: „Ha hiszik, ha nem, egy közösség problémáinak a megoldása pénzügyi oldalon is kifizetôdô" (Treuhaft, 2012). A közös értékteremtés érdeme tehát, hogy mindenképpen a gazdasági haszonszerzésre törekszik, miközben társadalmi értéket generál abban a közösségben, amelynek szerves részét képezi (Porter-Kramer, 2006).

A szakirodalom három utat határoz meg a közös értékteremtésre (Porter-Kramer, 2011):

- a termékek és piacok újragondolása;

- a termelékenység újradefiniálása az ellátási lánc egészében;

- kiterjesztett klaszterek létrehozása a vállalat telephelyének környezetében.

Az elsố lehetôség az addig kielégítetlen társadalmi szükségekre, hátrányos helyzetû́ közösségek megsegítésére épít. A megoldás elsôre kétséges, hiszen a forprofit tevékenységek méretgazdaságosságot, fizetôképes keresletet igényelnek, amely elsố pillantásra hiányozhat a képletból (Karnani, 2007). Amint látni fogjuk, számos esettanulmány mutatja, hogy kormányzati és nonprofit szervezetek bevonásával, támogatói klaszter létrehozásával ez az út is járható a profitérdekelt vállalatok számára (Gerencer-Preston, 2015).

A közös értékteremtés második útjának alapja, miszerint fenntartható gazdálkodás csak az ellátási lánc egészének bekapcsolásával folytatható (Szegedi, 2012). A beszállítók vagy a lánc más tagjainak támogatása elsố ránézésre költségtöbbletet jelent a vállalatok számára, azonban a teljes termelési és szolgáltatási folyamat produktivitását növeli, ami végeredményben a lánc egyes tagjainak hasznát is emeli (Spitzeck-Chapman, 2012). A második megoldás már-már klasszikusnak nevezhetố példája a Nestlé (2006) esettanulmánya, amely Porter és Kramer teóriáját is megtermékenyítette.

A harmadik szcenárió a helyi gazdaságfejlesztés kutatói számára már ismeretes, az iparági klaszterek kiterjesztett verzióját értjük ez alatt. Lényegében a Triple és Quadruple Helix-modellek által leírt menedzsmentet érvényesíti, a vállalkozások, kormányzati és nonprofit hatóságok, helyi társadalom és az oktatási intézmények bevonásával. A modell gyakorlati alkalmazhatóságát számos nemzetközi és hazai példa igazolja, melyek zömében multinacionális nagyvállalatok kezdeményezésére történnek. Különösen reneszánszukat élik a jármúipari központokkal kapcsolatos kutatások, az ingolstadti (Fekete, 2014a), továbbá a sindelfingeni és a neckarsulmi (Fekete, 2015a) jármúipari központ gazdaságfejlesztési modelljének feltárása, továbbá a hazai jó gyakorlatok az Audi győri központjával kapcsolatban (Czakó, 2014; Fekete 2014b). 


\section{Közös értékteremtés a gyakorlatban}

A 2000-es évek elejétôl egyre több vállalattal kapcsolatban olvashatunk olyan projektekrôl, amelyet valamilyen közösségi, társadalmi igény hívott életre, és a vállalat számára is új piacot teremtett. A közös értékteremtést támogató weboldal segítségével huszonnyolc esettanulmányt dolgoztam fel, a világ szinte minden pontját érintve. ${ }^{4}$ Az esettanulmányt adó vállalatok mérete viszonylag diffúz, legfeljebb 50 főt alkalmazó kisvállalattól egészen a 430000 fớt foglalkoztató multinacionális vállalatcsoportig. A cégméret is mutatja, hogy a leírt módszertan szinte bármilyen léptékben alkalmazható, azonban tény, hogy a vizsgált projektek zömében nagyvállalati kezdeményezésre történtek. A közös értékteremtésben érdekelt vállalatok ágazati besorolása is színes, habár legnagyobb számban élelmiszeripari, egészségügyi és energetikai vállalatok kerültek a mintába (3. ábra). A közös értékteremtés klasszikus példája a vizsgált adatbázisban élelmiszeripari vállalatokhoz köthetô. Viszszatérô példa, hogy nagyvállalatok - mint például a SAB Miller, CJ CheilJedang, Urbano Agroindustrial - termékfejlesztéssel és a gazdák vagy forgalmazók képzésével, támogatásával növelni tudják az ellátási lánc termelékenységét, erôsítve saját bevételüket is. Ennek kiváló példája a Nestlé érdekeltségébe tartozó, gabonapehely-gyártó Uncle Toby's, amely az ausztrál zabtermesztés visszaszorulását gátolta meg, a megváltozott klímaviszonyoknak megfelelố termény kifejlesztésével, ezzel a természetes diverzifikációt is megórizve. Nem mellesleg, a vállalatcsoport a gazdák támogatásának köszönhetôen, hat év alatt 500\%-os volumennövekedést ért el Ausztrália rurális területein (Leth, 2015).

3. ábra: A vizsgált mintában szerepló vállalatok gyakorisága iparáganként, ágazatonként

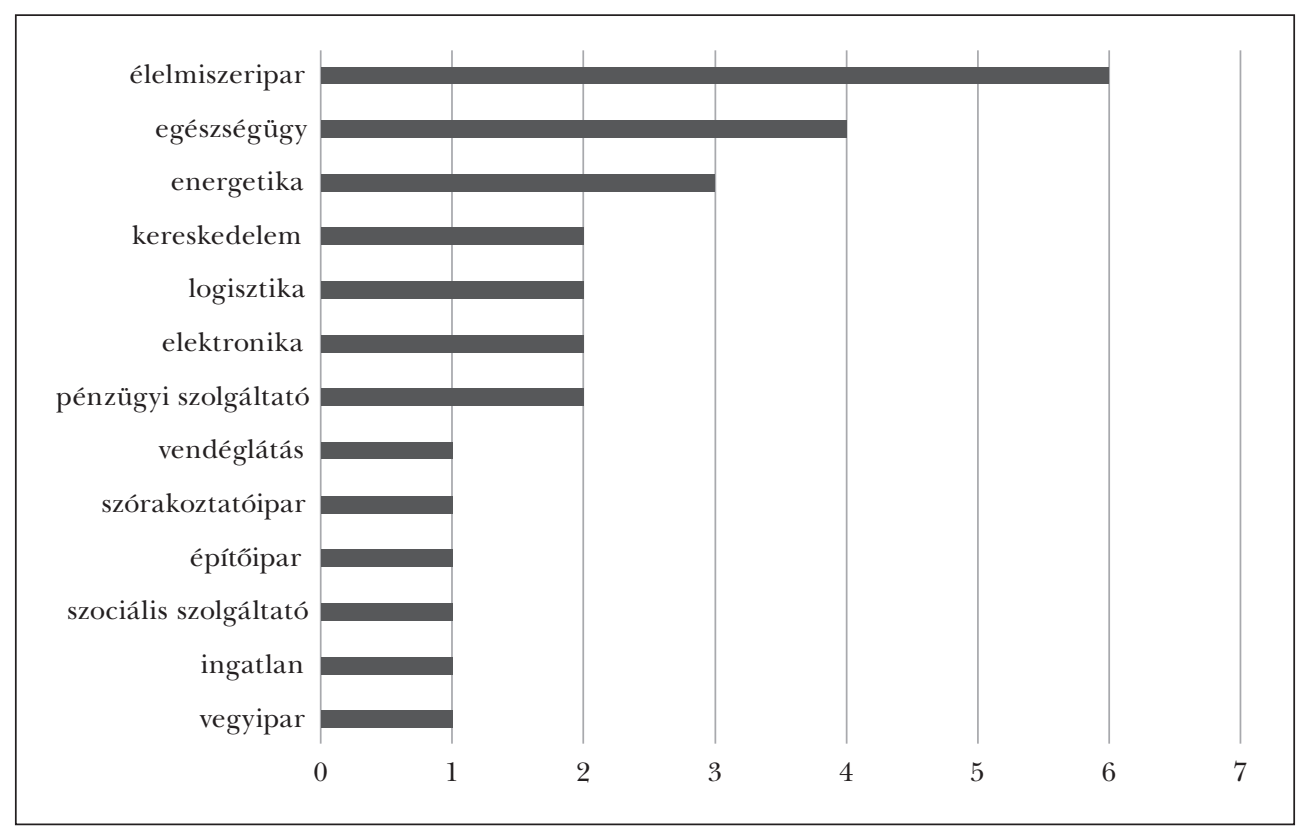

Forrás: Saját szerkesztés 
A vizsgált esetekben a közös értékteremtés alapja zömében társadalmi, kisebb arányban környezeti szükség volt, úgymint a kilakoltatás veszélye, a szeniorok jövedelemhiánya, a rurális térségek alacsony energia-, bankhálózati és kereskedelmi lefedettsége. A projektek általános haszna a kezdeti szociális igények kielégítése, a helyi gazdaság teljesítményének fokozása, új munkahelyek létrehozása és a projektet kezdeményezô vállalat forgalmának, népszerúségének növekedése volt.

\section{A MÚLT ÉS A JELEN ÖSSZEKAPCSOLÓdÁSA}

Az elmúlt két évtized vállalati esettanulmányait elemezve néhány kulcskifejezést fedeztem fel: bizalom, sáfárság, érintettek, bottom-up, rurális fejlesztés és alacsony jövedelmú közösségek. Az újra és újra felbukkanó szavak olvasása önkéntelenül is a Biblia gazdasági tanítását juttatta eszembe (1. táblázat). Ahogyan a Szentírás figyelmet fordít a hátrányos helyzetú csoportok megsegítésére, ugyanúgy a közös értékteremtés is gyakran éhezôkre, hajléktalanokra, adósságcsapdában élőkre fókuszál. Ugyan nem az adósságok elengedésével, de a vidéki térségek felvirágoztatásával a CSV-gyakorlat is a vagyoni és jövedelmi egyenlôtlenségek csökkentését segíti.

1. táblázat: A Biblia gazdasági tanitása felfedezhetô a közös értékteremtés modern gyakorlatában

\begin{tabular}{l|l}
\hline Bibliai gazdaságetikai elvek & Kapcsolódó CSV-stratégia \\
\hline $\begin{array}{l}\text { Társadalmi igazságosság, a rászorulók munká- } \\
\text { hoz juttatása }\end{array}$ & A termékek és piacok újragondolása \\
\hline $\begin{array}{l}\text { Adósságok elkerülése, csökkentése } \\
\text { Sáfárság }\end{array}$ & $\begin{array}{l}\text { A termelékenység újradefiniálása az ellátási } \\
\text { lánc egészében }\end{array}$ \\
\hline $\begin{array}{l}\text { Bottom-up gazdaságfejlesztés elônyben része- } \\
\text { sítése a hierarchikus struktúrákkal szemben, } \\
\text { bizalom, tisztességes verseny }\end{array}$ & $\begin{array}{l}\text { Kiterjesztett klaszterek létrehozása a vállalat } \\
\text { telephelyének környezetében }\end{array}$ \\
\hline
\end{tabular}

Forrás: Saját szerkesztés

A leírtak fényében talán nem túlzó azt állítani, hogy a Porter és Kramer által leírt értékteremtési módszertan bizonyos szinten a bibliai elvek modern adaptációjaként is megfeleltethető, természetesen napjaink gazdasági erôviszonyaihoz alkalmazkodva. Vannak ugyanis olyan bibliai elvek, amelyeket kizárólag a Szentföldön, konkrét feltételek teljesülése mellett lehetne betartani - például a szombatév vagy a jubileumi év törvénye -, de azok szellemisége felfedezhetô a közös értékteremtés gyakorlatában. Mindenesetre elmondható, hogy a publikációban részletezett elméletek és praktikák egységesen az alulról jövô, helyi gazdaságfejlesztésre támaszkodnak, azt preferálják.

A középkori zsidó rabbi, Maimonidész megközelítésében a társadalmi igazságosság legmagasabb fokát az a típusú jótékonykodás képviseli, amikor úgy segítünk valakin, hogy az illetô még nem szegényedett el, nem tekinthetó rászorulónak, például munkához, üzleti lehetôséghez juttatjuk (Háberman, 2013). A közös értékteremtés révén a 
vállalatok pontosan ezt teszik a helyi közösségben, amikor előnyben részesítik a lokális beszállítókat és partnereket. A Porter és Kramer által elméleti síkra is átterelt CSV ugyan további teoretikus elmélyítést és üzleti empíriákat kíván, gazdaságetikai szempontból mégis üdvözlendő a megjelenése.

\section{ÖsszeGzÉS}

Jelen tanulmány megközelítésének újszerúségét az adja, hogy az ôsi gazdaságetikai és -politikai irányelveket a jelenkor pozitív gazdasági példáival kapcsolja össze, különös tekintettel a helyi gazdaságfejlesztésre. A téma aktualitását korunk számos etikai hiányosságokból fakadó válsága és társadalmi dilemmája indokolja, érdemes ilyen szemmel olvasni a sorok között.

A dolgozat végéhez közeledve felvetődhet a kérdés, hogy milyen gazdaságpolitikai javaslatokat, tanulságokat vonhatunk le napjainkra nézve egy ilyen ôsi, a vallási irodalom egyik alapkövének számító könyvból. A Biblia alapján a gazdaság tartópillére és alapegysége a megfelelő jövedelmi viszonyokkal rendelkezô család. Gazdaságpolitikai szempontból - megítélésem szerint - minden nemzet kiemelt érdekévé és céljává szükséges tenni a családok támogatását, megélhetésük biztosítását. A mindenkori kormányok a bibliai elvekre támaszkodva ezt nem egyoldalú transzferjuttatásokkal biztosíthatják csak, hanem a családok gazdálkodását támogató jogrendszerrel, kamatmentes hitelekkel, amelyre a hazai gyakorlatból is találunk múködóképes példát.

Természetesen vannak és mindig is lesznek olyan csoportok, akik jobban igénylik a szociális háló fenntartó erejét, átmenetileg vagy élethelyzetükból fakadóan külsô támogatásra szorulnak. Számukra is elsốdlegesen a munkához való jutást, az emberhez méltó életkörülmények biztosítását kell szem elôtt tartania a gazdaságpolitikának, melynek nem célravezetô alternatívája a meggondolatlan segélyezés. A korábbi gondolathoz visszakapcsolódva, az erôs és biztos megélhetéssel bíró családok megalapozzák a társadalom anyagi biztonságát és terheket vesznek le az állami szociális költségvetésrôl. Bibliai elvekre támaszkodva a gyermekekrôl és a nyugdíjasokról való gondoskodás is elsốdlegesen a családok feladata, csak ezt követôen hárítható felelôsség az államra, ugyanakkor ennek előfeltétele, hogy a családok biztos egzisztenciával rendelkezzenek.

A közös értékteremtés előzô fejezetekben ismertetett gyakorlata azért is szerencsés, mert a fenti elveket szolgálja akkor, amikor a helyi közösségek anyagi megerősítését tûzi ki a zászlajára. Az ôsi és modern üzleti megoldások fényében a civil-központú Quadruple Helix-modell alkalmazását javaslom a gazdaságpolitika területi szereplői számára, hiszen csakis együttmúködés árán valósíthatóak meg a fent részletezett célok. Bizalom hiányában hosszú távon a vállalatok hitelképessége és a gazdaság versenyképessége is ingataggá válik, azonban a bibliai gazdasági normák alkalmazása és a közös értékteremtés véleményem szerint egységesen az együttmúködés irányába hatnak. 


\section{JEGYZETEK}

1 A tanulmány megírását a GINOP-2.3.4-15-2016-00003 azonosító számú projekt „5. KKV-k nemzetközi versenyképességét támogató szolgáltatások fejlesztése” alprojekt támogatta.

2 Mózes öt könyvét tartalmazó gyújteményes irat.

3 A protestáns Ószövetséggel megegyezô, történeti, profetikus, bölcseleti könyveket tartalmazó vallási szöveggyújtemény.

4 Shared Value esettanulmányok, forrás: https://sharedvalue.org/resources?keys=\&field_resource_type_ tid=96.

\section{FELHASZNÁLT IRODALOM}

Aharoni, Yohanan - Avi-Yonah, Michael (2004): Bibliai atlasz. Carta - Szent Pál Akadémia, Jeruzsálem-Budapest.

Arnkil, Robert et al. (2010): Exploring the Quadruple Helix. www.researchgate.net/profile/Robert_Arnkil/ publication/262026073_Exploring_the_Quadruple_Helix_Report_of_Quadruple_Helix_Research_ For_the_CLIQ_Project/links/0f31753673fe549303000000.pdf (Letöltés: 2017.június 10.).

Baba Mezi’a 50b - Babylonian Talmud. www.come-and-hear.com/babamezia/babamezia_50.html.

Baba Bathra 21b - Babylonian Talmud. www.come-and-hear.com/bababathra/bababathra_21.html\#PARTb.

Bod Péter Ákos (2006): Bevezetés a gazdaságpolitikába. Aula Kiadó, Budapest.

Bohács Zoltán (2015): Hitelamnesztia. Új Exodus, 22. évf., 2. sz., 66-71.

Cahn, Jonathan (2014): The Mystery of The Shemitah. Frontline, New York.

Carroll, Archie B. (1979): A Three-Dimensional Conceptual Model of Corporate Performance. The Academy of Management Review, vol. 4, no. 4., 497-505.

Chabad.org: Ethics of the Fathers (Pirkei Avot): Chapter One. www.chabad.org/library/article_cdo/aid/2165/ jewish/Chapter-One.htm (Letöltés: 2016. június 3.).

Csiszárik-Kocsir Ágnes (2016): Etikus pénzügyek, avagy a pénzügyek etikája. Polgári Szemle, 12. évf., 4-6. sz., 75-87.

Czakó Katalin (2014): Az Audi Hungaria Motor Kft. hatása a helyi gazdasági és társadalmi folyamatokra. Tér és Társadalom, 28. évf., 2. sz., 189-198.

Egység (1996): A kamat, a bankok és a zsidók. Egység, 24. sz., http://zsido.com/fejezetek/zsido-vilaghirado-36/.

Etzkowitz, Henry - Leydesdorff, Loet (1996): The Triple Helix of University-Industry-Government Relations. A Laboratory for Knowledge Based Economic Development. EASST Review, vol. 14, no. 1., 11-19.

Fekete Dávid (2014a): Gazdaságfejlesztés az ingolstadti jármúipari központban. Tér és Társadalom, 28. évf., 2. sz., 176-187.

Fekete Dávid (2014b): Gyôr aktuális jövôképe a város stratégiai dokumentumainak tükrében. In: $A$ városi rendszer múködése. Közösségi szféra, oktatás és Györ jözóképe. Szerk. Dusek Tamás, Universitas-Győr Nonprofit Kft., Gyôr, 180-187.

Fekete Dávid (2015a): Délnémet jármúipari központok: Sindelfingen és Neckarsulm. In: Nyugat-és kelet-középeurópai jármúipari térségek múködési modelljei. Szerk. Fekete Dávid, Universitas-Gyôr Alapítvány, Gyôr, 19-29.

Fekete, Dávid (2015b): The Operational Characteristics of European Automotive Industry Centers. In: New Regional Economic Development Methods of European Automotive Industry Centers. Ed. Dávid Fekete, Universitas-Győr Alapítvány, Gyôr, 7-19.

Filep Bálint (2014): A nagyvárosok az európai és a magyar területi politikában. Publikon Kiadó, Pécs-Gyôr.

Friedman, Hershey H. (2000): Biblical foundations of Business Ethics. Journal of Markets and Morality, vol. 3, no. 1., Spring, 43-57.

Friedman, Hershey H. - Fischer, Dov (2013): Ethics of the Fathers: A Tool for Improving the World. Brooklyn College, New York, http://papers.ssrn.com/sol3/papers.cfm?abstract_id=2267122 (Letöltés: 2016. május 10.), http://dx.doi.org/10.2139/ssrn.2267122.

Fukuyama, Francis (1997): Bizalom. Európa Könyvkiadó, Budapest. 


\section{Polgári Szemle · 13. évfolyam 1-3. szám}

Gerencer, Eva - Preston, Phil (2015): Reducing Homelessness Through Commercial Initative for Real Estate Agents. https://sharedvalue.org/sites/default/files/resource-files/CASE\%20STUDY-\%20MREEP.pdf (Letöltés: 2017. június 10.).

Geva, Aviva (2008): Three Models of Corporate Social Responsibility: Interrelationships Between Theory, Research and Practice. Business and Society Review, vol. 113, no. 1., 1-41., http://dx.doi.org/ 10.1111/j.1467-8594.2008.00311.x.

Grüll Tibor (2013): Szépség és szörnyeteg. Az európai múvelódés története I. Az ókortól a reneszánszig. Hetek Könyvek, Budapest.

Gyôri Zsuzsanna (2012): Elsô- és másodfajú etikai kudarcok. Vezetéstudomány, 43. évf., 10. sz., 56-63.

Háberman Zoltán (2013): Cedaka és társadalometika. OR-ZSE, Budapest, http://mek.oszk.hu/13600/13600/ 13600.pdf (Letöltés: 2016. június 5.).

Hack Márta (2014): Egy népszerú ünnep újjászületése: a szombatév. Hetek, www.hetek.hu/hit_es_ertekek/201410/egy_nepszeru_unnep_ujjaszuletese_a_szombatev (Letöltés: 2017. május 31.).

Józsa Viktória (2017): A nagyvállalati beágyazódás vizsgálata helyi szinten három magyar nagyváros példáján. PhD-értekezés, Szent István Egyetem, Gödöllő.

Karnani, Aneel (2007): The Mirage of Marketing to the Bottom of the Pyramid: How the Private Sector Can Alleviate Poverty. California Management Review, vol. 49, no. 4., 90-111., https://doi.org/10.2307/ 41166407.

Károli Gáspár (ford.): Szent Biblia, azaz az Istennek Ó- és Újszövetségében foglaltatott egész Szentírás. Patmos Records, Budapest, 2012.

Lentner Csaba (2014): A magyar önkormányzatok adósságkonszolidációja. Pénzügyi Szemle, 59. évf., 3. sz., 330-344.

Lentner Csaba (2015): Az új magyar állampénzügyi rendszer - történeti, intézményi és tudományos összefüggésekben. Pénzügyi Szemle, 60. évf., 4. sz., 458-472.

Leth, Melinda (2015): Uncle Toby's: Sustainable Oat Production in Rural Australia. https://sharedvalue.org/resources/uncle-toby\%E2\%80\%99s-sustainable-oat-production-rural-australia (Letöltés: 2017. június 6.) .

Maimonidész (n. a.): A birtokbavétel könyve - A rabszolgák szabályai. http://zsido.com/fejezetek/a-birtokbavetel-konyve-a-rabszolgak-szabalyai/.

Nestlé (2006): The Nestlé Concept of Corporate Social Responsibility. https://sharedvalue.org/sites/default/files/ resource-files/Nestle_Corporate_Social_Responsibility_in_Latin_America.pdf (Letöltés: 2017.június 5.).

NIV (2011): New International Version Study Bible. Zondervan, Grand Rapids, Michigan.

North, Gary (1973): An Outline of Biblical Economic Thought. In: An Introduction to Christian Economics. The Craig Press, US.

Oehler, Gustav F. (1883): Theology of the Old Testament. Zondervan, Grand Rapids.

Porter, Michael E. - Kramer, Mark R. (2006): Strategy and Society: The Link Between Competitive Advantage and Corporate Social Responsibility. Harvard Business Review, vol. 85, no. 12., 78-92.

Porter, Michael E. - Kramer, Mark R. (2011): Creating Shared Value. How to Reinvent Capitalism - And Unleash a Wave of Innovation and Growth. Harvard Business Review, January-February.

Rechnitzer János et al. (2016): A Gyôri Modell - Az egyetem, az ipar és a város együttmúködési dimenziói. In: Térségek versenyképessége, intelligens szakosodása és újraiparosodása. Szerk. Lengyel Imre, Nagy Benedek, JATEPress Kiadó, Szeged, 225-239.

Schmidt, Alvin J. (2004): How Christianity Changed the World. Zondervan, Grand Rapids.

Sedlacek, Tomas (2012): A jó és a rossz közgazdaságtana. HVG Könyvek, Budapest.

Sola Scriptura (2012): Bírák kora és az egységes királyság. Sola Scriptura Fóiskola, www.sola.hu/segedanyagok (Letöltés: 2017. május 13.).

Solt, Frederick (2016): The Standardized World Income Inequality Database (SWIID), https://doi.org/10.1111/ ssqu. 12295 .

Spitzeck, Heiko - Chapman, Sonia (2012): Creating shared value as a differentiation strategy - the example of BASF in Brasil. Corporate Governance, vol. 12, no. 4., 499-513., https://doi.org/10.1108/ 14720701211267838.

Szegedi Zoltán (2012): Ellátásilánc-menedzsment. Kossuth Kiadó, Budapest. 
Tamari, Meir (n. a.): Bizonytalanság, kapzsiság és az üzleti erkölcs. Kezdhetünk-e valamit az ember fáradhatatlan mohóságával? http://zsido.com/fejezetek/vagyon-es-penz-bizonytalansag-kapzsisag-es-az-uzleti-erkolcs/ \#_ftn7 (Letöltés: 2016. június 10.).

Tokics Imre (2011): A ius talionis és az asylum városok jogi, vallási és kultúratörténeti jelentôsége a Tanakban. PhDértekezés, OR-ZSE, Budapest.

Treuhaft, Sarah (2012): A Business Model That Brings Jobs, Health, Services - and Joy - to the Hardest Hit Communities. www.huffingtonpost.com/sarah-treuhaft/a-business-model-that-bri_b_1914585.html?utm_hp_ ref=opportunity-working (Letöltés: 2017. június 12.).

Weber, Max (2007): Világvallások gazdasági etikája. Gondolat Kiadó, Budapest.

White Jr., Lynn (1967): The Historical Roots on Our Ecologic Crisis. Science. In: Természet és szabadság. Szerk. Lányi András, Osiris Kiadó, Budapest, 2000. 